\title{
Vacuolar Protein Sorting-Associated Protein 35
}

National Cancer Institute

\section{Source}

National Cancer Institute. Vacuolar Protein Sorting-Associated Protein 35. NCI

Thesaurus. Code C99647.

Vacuolar protein sorting-associated protein 35 (796 aa, $\sim 92 \mathrm{kDa}$ ) is encoded by the human VPS35 gene. This protein is involved in the mediation of protein sorting. 